\title{
Immigrant Small Business in Sweden: A Critical Review of the Development of A Research Field
}

\author{
Zoran Slavnic ${ }^{1}$ \\ ${ }^{1}$ REMESO, Linkoping University, SE 60174 Norrkoping, Sweden \\ Correspondence: Zoran Slavnic, REMESO, Linkoping University, SE 60174 Norrkoping, Sweden. Tel: \\ 46-11-363-211. E-mail: zoran.slavnic@liu.se \\ Received: January 7, 2013 \\ Accepted: February 14, 2013 \\ Online Published: February 18, 2013 \\ doi:10.5430/jbar.v2n1p29 \\ URL: http://dx.doi.org/10.5430/jbar.v2n1p29
}

\begin{abstract}
This paper examines the current state of immigrant small business research (ISBR) in Sweden, discusses the main trends in the field and presents the key texts that represent these trends. It is noted that research in the 1990s was largely influenced by the current political agenda, while academic communication between Swedish and international ISBR on the one hand, and Swedish ISBR and Swedish 'mainstream" small business research (SBR) on the other were conspicuous by their absence. Besides, only a few researchers in the field were able to conduct their research in a systematic manner or with stable and long-term funding of research teams. The situation has changed in the 2000 s. This period was characterized by increased academic interest in immigrants' small businesses. Researchers dealing with ISBR wanted to free themselves from the current political agenda as well as from the focus on domestic priorities in terms of research questions and methodology. This has resulted in a large number of published policy-critical texts. At the same time the research interest shifted towards the previously neglected aspects of immigrants' small businesses, such as immigrant women in business, young immigrants and immigrant entrepreneurship in the high-tech sector. These studies were based both on ambitious quantitative survey and on refined qualitative micro-studies. This critical review concludes with the discussion of a possible future research agenda for ISBR.
\end{abstract}

Keywords: Ethnic business in Sweden, Small business, Ethnic minority business

\section{Introduction}

This paper presents and analyzes research on immigrants' small businesses (ISBR) in Sweden. The main aim of the paper is to critically examine the current state of immigrant small business research (ISBR) in Sweden, discuss the main trends in the field and a possible future research agenda for ISBR. We start with a brief description of international research on small businesses among immigrants.

International research dealing with immigrants' small businesses emerged as a separate academic field as early as 1972 , when the American sociologist Ivan Light published his book Ethnic Enterprise in North America (Kloosterman \& Rath 2003; Waldinger 2001). From the beginning, the field was dominated by cultural explanations. This research tradition has its origin in the United States and is the result of American economic, political and social circumstances, but tradition has also significantly affected ISBR in Europe, including Sweden to some extent.

Several theories are relevant in this context. During the 1970s so-called middleman minority theory, launched by the American sociologist Edna Bonacich (1973), was very influential. Put briefly, Bonacich showed how minority groups, in order to cope with discrimination and other stresses they were exposed by the majority community, intensified their group solidarity, which in turn affected their economic activities. Mutual trust and loyalty results mainly in a more efficient allocation of resources within the group, but it also eliminated competition within it.

This initial theoretical argument resulted over time in the establishment of several new concepts in the field. One of them was the concept of 'ethnic economy', encompassing any minority ethnic or immigrant employees, employers or self-employed workers (Bonacich \& Modell 1980). Another concept related to ethnic economy (that is, mutually dependent ethnic enterprises in a geographically limited area, oriented towards ethnic customers) was that of 'ethnic enclave economy’ (Wilson \& Portes 1980; Wilson \& Martin 1982).

Since the mid-1980s the research field has been strongly influenced by the concept of 'embeddedness', which was developed by, among others, Granovetter (1985), Portes \& Sensenbrenner (1993), and Waldinger (1995). The concept emerged as a (sociological) reaction to the blindness of neoclassical economics to social relations within the economy. 
According to Granovetter (1985:483), the dominant perception of economic actors in neoclassical economics is too simple; in his words they are 'atomized and undersocialized', driven solely by rational calculation of self-interest. In contrast, Granovetter argues that all social action, including economic action, is embedded in the structures of social relations between players.

Although the concept of embeddedness itself contained an effective critique of the shortcomings and bias of neoclassical economics, it was still applied in a rather one-sided way within ISBR. The focus was still primarily on the cultural aspects of migrant entrepreneurship, while the broader political, economic and social context was more or less neglected. Nevertheless, embeddedness in an ethnic group became a central concept in the study of immigrants' social and economic integration into mainstream society. In this context, their ethnic resources were crucial (Light, 1984; Light \& Bonacich 1988; Light \& Karageorgis 1994; Light \& Gold 2000). Meanwhile, the broader context of the capitalist (regulated) market in which small ethnic entrepreneurs were engaged was taken for granted and treated as unproblematic.

The above theories and approaches have substantially affected the development of ISBR in Europe. In the Netherlands, for example, research on ethnic minorities in general, and ISBR in particular, were during the 1990s largely framed by the so-called 'ethnicity paradigm (Rath 2001). In this paradigm, ethno-cultural differences are the main basis of social disparities. On the basis of such ideas, most studies reduce immigrant entrepreneurship to an ethno-cultural phenomenon, existing in a total economic and institutional vacuum. In this sense, Rath (2001) characterizes ISBR in Holland in the 1990s as a special case of so-called academic provincialism.

The situation in Britain has long been little better (Note 1). Although these British studies, as well as a number of other important studies in the 1990s and especially during the 2000s identified the importance of the current structural changes in the so-called advanced economies for the study of immigrants' small businesses, ethno-cultural explanations have remained dominant in the field (Ram \& Jones 2008). This approach over time has admittedly become less categorical (see for instance so-called "interactive" model presented by Waldinger, 1986, 1989; Waldinger et al. 1990), but it is still dominant. Nevertheless, it is also clear that the vibrant academic debate within ISBR in the 2000s resulted in the dynamic development of ISBR in both the Netherlands and Britain.

The academic debate, then, resulted in changes in both methodological and theoretical perspectives on immigrants' small businesses. The most influential concept in recent years has been that of 'mixed embeddedness, (Note 2) which tries to reconcile the two established traditions, namely, the focus on what is ethnic in ethnic entrepreneurship on the one hand, and the impact of broader structural processes on the other hand. Rath, Kloosterman and their colleagues do not deny the importance of social networks for immigrants' social and economic integration, but the essence of their approach is systematically to connect what is happening in these networks to the political, economic and social processes taking place at a broader structural level.

Apart from this academic debate on major theoretical and methodological issues, the current situation in the field is characterized by several other significant trends. One such trend is the application of the biographical method. (Note 3) Another is the differentiation of the field into a number of sub-fields, specializing in, for example, women's entrepreneurship among immigrants, (Note 4) second-generation business (e.g. Portes \& Rumbaut 2001), and young entrepreneurs with an immigrant background (e.g. Williams 2004).

At the same time, more serious international comparative studies on various aspects of immigrant entrepreneurship are lacking, because some countries have no statistics on immigrants' small businesses. In other countries, data on small immigrant businesses is sorted into various statistical categories, making it difficult to obtain relevant data in context, and even more difficult to compare them (Kloosterman \& Rath 2003). Moreover, ISBR priorities often vary in different countries, different concepts and methods are used, and different relationships are established with their respective national policy debates (Kloosterman \& Rath 2003: 12).

My aim in this paper is to discuss how the methodological, empirical and theoretical development of ISBR in Sweden fits into the international trends described above.

\section{1990s ISBR: policy-supporting research in Sweden}

Since the second half of the 1980s in Sweden there has been increasing political interest in small business in general and immigrants' small businesses in particular. One important consequence of this interest was that it helped to establishing ISBR. Another effect was that in the 1990s Swedish ISBR came under the strong influence of the future policy agenda. The vast majority of ISBR studies were published by governmental organizations, institutions and authorities were behind; only a few during the same period were published by academic institutions. For example, 
during the 1990s only one text, written by Swedish author (Khosravi 1999) was published in an international scientific journal.

The obvious problem encountered by social scientists in such a situation is that their scientific priorities have to be harmonized with the imperative that research results be 'practically applicable'. This is best illustrated by the following quotation from Pripp's dissertation (2001a:15):

The disadvantage was that the first years of my doctoral studies were overly characterised by commissioned research as well as by its orientation toward producing practically applicable knowledge. I devoted myself to sketching the model of causal relations instead of trying to approach the field in a more unbiased way. I also adopted the government's perspective, more or less, by assuming that my dissertation would offer guidance for skill-development measures and education of would-be entrepreneurs. It was only much later that I began examining how the entrepreneurs in question were treated by their social and institutional surroundings. (Author's translation)

The political expectations related to small businesses were not only to enhance the flexibility of the system by increasing differentiation, but also to help promote social welfare. The small business sector would accomplish this by reducing unemployment and increasing growth and prosperity, thanks to the spirit of innovation thought to be inherent in small-scale entrepreneurship. Immigrants' small businesses have been expected both to reduce unemployment among immigrants and to help integrate immigrants into Swedish society in general.

This view of the role that small businesses, including immigrants' small businesses, should play is more or less taken for granted in most research on immigrant businesses in Sweden, and most of the texts appear to accept it implicitly. In other words, the official 'reformist' position is accepted as being basically correct and justified. From this perspective, the job of social science is to indicate the possible obstacles to political change, so that politicians can formulate political measures to remove these obstacles.

The above quotation from Pripp, however, shows that the connection between political expectations and the role of research was by no means problem-free. As a result, at the beginning of the $2000 \mathrm{~s}$ academic texts increasingly began to question both the politicians' expectations and the research approach to these expectations.

\section{2000s ISBR: policy criticism}

Production of policy-supporting texts did not decrease during the 2000s, but the parallel production of independent academic texts (hereinafter called policy critical ISBR) increased significantly.

Oskar Pripp's thesis from 2001, which, incidentally, was the first doctoral dissertation on ISBR, depicts the cultural categorization of immigrants' small businesses. His study highlights the strategies employed by immigrants to deal with various problems arising from cultural stereotyping and categorizing of their activities. In another text (2001b) Pripp describes strategies that Assyrian and Syrian entrepreneurs develop in response to the stereotypes about them and their businesses: they are treated as a homogeneous group and defined almost exclusively in ethnic terms by the authorities, the media and the most of their customers. At the same time, the entrepreneurs themselves rarely describe their families and ethnically based business networks in ethnic terms. 'Common ethnicity, however, was not sufficient to enable potential entrepreneurs to borrow money from their relatives, friends or acquaintances. More important was the lenders' perception of the person's personal qualities' (Pripp 2001b: 107).

Shahram Khosravi (2001), based on his study of Iranian entrepreneurs in Stockholm, criticizes a simplistic view of the role of ISBR in relation to the social integration of immigrants, where immigrants are considered as a homogeneous group regardless of their backgrounds, the differences between them and their reasons for migration.

Zoran Slavnic (2001) points out problematic status that the notion of the informal economy has within the research community, where it is almost exclusively related to small businesses, and first and foremost to immigrant small businesses. At the same time the business activities of large companies, as well as of various state institutions, are conceptually treated a priori as free of 'informality'.

On the decision to start up a small business, policy critical ISBR in Sweden (Mason \& Ålund 2001; Andersson \& Wadensjö 2004b; Darin 2006; Ljungar 2007; Alici 2007) has shown that the main factors contributing to the immigrants' decisions whether to start their own businesses is discrimination on both structural and individual levels, an absence of recognition of their previous education as well as their professional experience and skills, the extreme difficulty in getting a job on the Swedish labour market, and a strong desire to avoid passivity and dependence on social assistance. 
At the same time, self-employment does not contribute either to improving immigrants' standards of living or to reducing their social exclusion (Slavnic 2001; 2004; Ålund 2003; Abbasian 2001; 2003). In fact, most self-employed immigrants are worse off economically than immigrants with regular employment (Hjerm 2001; 2004). They even have much lower incomes than Swedish-born entrepreneurs (Andersson \& Wadensjö 2004a; 2004b; Andersson 2005; 2006). One possible explanation for these differences, according to the authors cited, is that in the small business sector a high degree of discrimination forces entrepreneurs with foreign backgrounds to sell their goods and services at lower prices. A more recent study (Ahmed, Andersson \& Hammarstedt 2009) shows that immigrants are discriminated against even when they want to buy other established companies.

In speaking of discrimination against business owners with foreign backgrounds, it is important to note that the problem has been addressed, both as a concept and as a phenomenon, in several other reports and studies (SOU 2003:17; Lange 2005; NUTEK 2005; see also Wokander (2004), which shows how immigrants face systematic discrimination by the authorities). As a concept, discrimination is rather ambiguous and unclear. Furthermore, the phenomenon is difficult to measure, with the result that the research results vary depending on how researchers define the term (e.g. the difference between perceived discrimination and actual discrimination) or how it is measured. The only thing everyone agrees on is that more research is needed to obtain more reliable knowledge about this phenomenon.

In conclusion, it may be said that the wave of policy-critical texts cited above has in recent years contributed positively to the development of ISBR. With its academic output, including several dissertations and a number of articles published in various international social scientific journals, it has contributed to the establishment of the research field nationally and internationally. Another important result of the emergence of critical voices in the field is that a certain tension has developed between the so-called policy-critical texts and the so-called policy-supporting production of knowledge about immigrants' small businesses. This tension has not blocked the further development of ISBR, but has instead led to more differentiated research focusing particularly on several previously neglected aspects of immigrants' small businesses, such as immigrant women in business, second-generation immigrant business, and immigrant entrepreneurs in the high-tech sector. A third result of the critical wave in ISBR is that several important texts have been published that adopt a reflexive approach to both policy and research on the one hand and scientists' role in this context on the other (see e.g. Mason 2002; Hultman 2006).

\section{Ethno-cultural versus structural explanations}

A fact that needs to be discussed is that the American research tradition, mainly based on ethno-cultural understanding, has exerted less influence in Sweden than in some other countries. Of course, Swedish ISBR has not entirely escaped its influence, but so far, in both the 1990s and the 2000s, ethno-cultural explanations have influenced Swedish media economic, political and policy-oriented discourses more than academic ones.

It is true that during the 1990s some researchers (see e.g. Najib 1999; 2000) had to argue against these ethno-cultural assumptions about immigrant small business to the effect that immigrants' business methods are characterized by a particular business culture that distinguishes their businesses from those of native Swedes. Such assumptions, according to Najib, have given rise to various myths about immigrant small business, such as that immigrants are exclusively pizzeria owners, or that immigrant small business is an exclusively male affair. Najib shows that immigrants run not only pizzerias but also other enterprises - essentially in all economic sectors except agriculture. He also shows that the average immigrant entrepreneur is better educated, but younger and with somewhat less specific professional experience, than his or her native Swedish counterpart. Many immigrant entrepreneurs have business backgrounds, are ambitious, and want to develop as well as educate themselves. They often belong to social networks of their compatriots, but such networks are not as broad as those of native-born Swedes. In general, there are no major differences between immigrants' and native Swedes' businesses (Najib 1999: 79).

From the beginning there were also academic studies that were more inspired by the 'ethnicity paradigm' (see e.g. Rojas 1993; 2001; Bevelander, Carlson \& Rojas 1997), but this tendency was certainly not dominant in Swedish ISBR.

There are several possible reasons for this resistance. One is that ISBR in Sweden in the 1990s was still an underdeveloped area of research, virtually uninfluenced by international development trends in the field (Slavnic 2004). Another, perhaps more important, reason is that many of the researchers who joined ISBR field at that time, and who led the policy-critical research in Sweden, came from the research field of international migration and ethnic relations (IMER). IMER was established in Sweden in the early 1970s, and gradually evolved into an influential national and international field of research. The main focus of Swedish IMER was original empirical and theoretical studies, which critically reassessed the ethno-cultural approach to migration, ethnicity and the integration of immigrants into their new homelands. With such an academic tradition in their luggage, scientists who joined ISBR 
strongly criticized the reductionism of the 'ethnicity paradigm' and at the same time pointed to the structural causes of immigrant small businesses' current situation. Observers quickly related this trend to similar trends in other European countries, especially in the Netherlands and Britain.

\section{The relationship between ISBR and mainstream small business research in Sweden}

Another interesting issue relating to ISBR in Sweden is its relationship with small business research (SBR) in general. In 1997147 researchers were engaged in SBR (Aronsson 1997), of whom 65 (46 per cent) were senior researchers. These researchers came from ten tertiary academic institutions, six researchers came from the college in Växjö, and 21 came from institutions in Stockholm. In the period 1959-97, 80 Ph.D. or licentiate dissertations within this field of study were defended. In 1986-97 alone, 51 dissertations were produced, and 17 in 1996-97. Hans Landström and Bengt Johannsson studied 35 doctoral dissertations that were defended during the same period at Swedish universities. Two studies (Aronsson 1997; Landström \& Johannson 1998) lead to a number of conclusions, which pertain to the sociology of science.

First, the ISBR community is much smaller than the SBR community - which is reasonable, given that the number of immigrant small businesses is also smaller. As well, the ISBR community consists primarily of researchers who either operate outside any organized research team or just occasionally examine immigrant small businesses. Researchers active in SBR are generally part of a more stable research community, with more or less stable finances. Moreover, most SBR researchers are active in institutions of economics or business administration, while the majority of ISBR researchers are active in institutions of cultural geography, economic history or political science.

Second, none of the 35 dissertations mentioned in Landström and Johannisson (1998) deals with immigrant small business. This is interesting because between 1990 and 1997 (in 1990-95 15 small business dissertations were defended) the number of immigrant enterprises increased from 22,000 to as many as 65,000 (SOU 1999: 49), or approximately 14 per cent of all small firms in Sweden. It is thus somewhat puzzling that mainstream SBR pays so little attention to immigrant small business: ignoring features specifically relating to 14 per cent of their research object severely limits the value of their observations and conclusions. At the same time, among the ISBR texts I have studied, only two cite any of the 35 dissertations mentioned by Landström and Johannisson (1998). So just as the observations and conclusions of Swedish SBR in general in Sweden are generally devalued by their neglect of immigrant small businesses, the credibility of ISBR is severely compromised by its neglect of Swedish SBR in general.

Third, it is quite puzzling from the perspective of the sociology of science that most researchers involved in SBR are native Swedes, while most researchers involved in ISBR are immigrants. We seem to be dealing with an issue akin to the 'insider's doctrine' as expounded by Merton (1973). In other words, it appears to be assumed that immigrants are better placed to understand and explain the phenomenon of immigrant small business, while only native Swedes can deal with small business in general, as it is dominated by native entrepreneurs. In addition, it may even be that, insofar as immigrant business is of lower status in the small business sector, ISBR and researchers in this field have a lower status in the research community. The findings presented at the beginning of this section may support such a conclusion.

During the 2000s, however, this situation started to change. Citation frequency has increased slightly in both fields of study, and in 2007 the first SBR dissertation on immigrants' small businesses was presented. A dissertations by Ahmad Ahmadi (2007), defended at the School of Economics and Commercial Law at the University of Gothenburg, discusses the entrepreneurial process in several growing small businesses owned by persons of immigrant background, and also the role of certain relevant social institutions in this process. In addition, the School of Economics at Växjö University (Note 5) in its Centre for Labour, Migration and Ethnic Relations started producing more and more academic texts in ISBR. (Note 6)

\section{Current trends in ISBR in Sweden}

It has already been pointed out that policy-critical research in Sweden created tensions both between the various research orientations within ISBR and between research and policy expectations related to immigrants' small businesses. These tensions, however, did not prevent ISBR's continued development; rather, they resulted in increased interest in ISBR, as well as in larger and more differentiated knowledge production in the field.

One example of this is research in that on women's entrepreneurship, which showed significant development in the 2000s - resulting in several dissertations being defended (Näsman 2000; Björnsson 2002; Pettersson 2002). It must, however, be stressed that this development has taken place in a context of generally increasing interest in women's entrepreneurship. The Swedish Agency for Economic \& Regional Growth (NUTEK) alone produced over 40 different publications on women's entrepreneurship between 2000 and 2007. 
Just as rapid had been the development of the trend of research on immigrant women in business. Dissertations by Suzanne Mason (2002) and Saied Abbasian (2003) are the most important works in this context, which together with other academic texts have been published internationally (e.g. Mason \& Ålund 2001; Mason 2003; 2007, see also Joona \& Wadensjö 2008). The have led Swedish research on immigrant women in business, which has established itself well internationally.

Another trend that has been emerging in recent years is research on small businesses by young people with immigrant background (Lundqvist 2006a; 2006b; 2010). The development of ISBR in recent years has also been characterized by increased interest in immigrants' small businesses in high-tech sectors (Dalhammar \& Brown 2005; Feldman 2006).

Researchers have also noticed that deregulation in the 1990s resulted in tougher conditions in certain economic sectors, which in turn led to an increased concentration of immigrants in precisely these sectors, both as entrepreneurs and as employees. Slavnic \& Urban (2008) in their quantitative study on the ethnification of the Swedish taxi industry have described how the economic conditions of individuals working in the taxi industry changed during 1990-2004 and how this affected the ethnic composition of the taxi industry over the same period.

Another phenomenon that is often associated with small businesses in general and immigrants' small businesses in particular (see e.g. Skatteverket 2004) is the informal economy, which has also attracted researchers' interest. Unlike the previous simplified approach and the associated cultural explanations of the phenomenon, Slavnic $(2001 ; 2006$; 2007; 2010; see also Likic-Brboric 2007) connects process of informalization of the economy to the broader structural changes that characterize contemporary Western (capitalist) welfare societies. Informalization is accordingly defined as a consequence of a profound structural conflict between the new regimes of accumulation (focusing on neoliberal flexibility) and the old (welfare) regulatory framework, which was designed with the objective of protecting employees from 'pure market forces' (Slavnic 2006; 2007, 2010, 2011, 2012).

\section{Concluding discussion}

This presentation of Swedish ISBR has not sought to tap every text that has been published in the field, but to give a general picture of the development of the field, to discuss the main trends in its development and to present the key texts that represent these trends. It was noted that research in the 1990s was largely influenced by the current political agenda, while academic communication between Swedish and international ISBR on the one hand and the Swedish ISBR and Swedish 'mainstream' SBR generally was conspicuous by its absence. In addition, only a few researchers in the field were able to conduct their research in a systematic manner or with stable, long-term finance for research teams.

The situation changed in the 2000s. This period has been characterized by increased academic interest in immigrants' small businesses. Researchers dealing with ISBR want to free themselves from the current political agenda as well as from the focus on domestic priorities in terms of research questions and methodology. As a result, a large number of policy-critical texts have been published, as well as texts with a reflexive approach to both political agendas and research agendas. At the same time, researchers' interest has been shifting towards the previously neglected aspects of immigrants' small businesses, such as immigrant women in business, young immigrants and immigrant entrepreneurship in the high-tech sector. These studies are based both on ambitious quantitative surveys and on refined qualitative micro-studies.

The important thing here is that Swedish ISBR has begun to evolve in response to the international ISBR context on the one hand and the Swedish 'mainstream' SBR context on the other. We are hopefully in the initial stages of work which in the future will develop into integrated, systematic and serious research on these issues. However, to be able to 'embed itself' in international ISBR, Swedish ISBR needs to include more international comparative studies.

The research questions that still await answers are as follows: Has the shift in the political focus to small and medium-sized enterprises, which took place a few decades ago, and as discussed earlier in this overview, actually resulted in a more favourable political and economic climate for small businesses in general and for immigrants' small businesses in particular? What distinguishes the climate in Sweden from that in other industrialized countries? Are there regional differences in Sweden, and how do they affect the opportunity structures for small entrepreneurs with an immigrant background? What is the situation, both for small business owners and for their companies, at the local level where real life is lived? How do immigrant-owned small businesses differ among the various economic sectors? In order to answer these questions, we need more research, both large comprehensive quantitative studies and small sophisticated qualitative studies on specific individuals' everyday strategies.

Finally, there is one thing that social science cannot achieve, namely, to bridge the gap between policy goals and policy practice. This can be achieved only by political leaders and policymakers. Research can help by continually striving to 
bridge the gap between the social reality we live in and our knowledge of this reality. This study hopefully makes a small contribution to that effort.

\section{References}

Abbasian, S. \& Bildt C. (2007). 'Kvinnors egenföretagande inom upplevelseekonomin: Berättelser från Degerfors och Gotland', in Stockholm: Arbetslivsinstitutet - Arbetsliv i omvandling | 2007:2.

Abbasian, S. (2001). 'Varför och hur blev vi egenföretagare i Sverige? tre iranska kvinnor berättar, in: Invandarrapport. Borås: Immigrant-institutet'.

Abbasian, S. (2003). Integration på egen hand. En studie av invandrade kvinnoföretagare i Sverige. Uppsala: Institution för Ekonomisk Geografi, Uppsala universitet.

Abbasian, S. (2004), 'Integration i arbetslivet genom egenföretagande : är det möjligt för invandrade kvinnor?' in Norrköping Integrationsverket.

Ahmadi, A. (2007). Möten mellan institutioner som drivkraft för den entreprenöriella processen. Göteborg: School of Economics and Commercial Law, Göteborg University.

Ahmed, A. M., Andersson, L. \& Hammarstedt, M. (2009). 'Ethnic Discrimination in the Marketplace of Small Business Transfers', Economics Bulletin No 4. Växjö: Department of Economics and Statistics, Linnaeus University.

Alici, G. (2007). Integration på arbetsmarknaden. En studie av personer med utländsk bakgrund. Luleå: Institutionen för arbetsvetenskap - Avdelningen för industriell produktionsmiljö, Luleå tekniska universitet.

Alund, A. (2003) 'Ethnic Entrepreneurs and Other Migrants in the Wake of Globalization', International Review of Sociology 13(1): 77-86. http://dx.doi.org/10.1080/0390670032000086998

Andall, J. (2000). Gender, Migration and Domestic Service: The Politics of Black Woman in Italy. Aldershot: Ashgate.

Andersson, J.P. \& Wadensjö, E. (2008). 'A Gender Perspective on Self-Employment Entry and Performance as Self-Employed', in IZA DP No. 3581: Bonn: Institute for the Study of Labor.

Andersson, L. \& Hammarstedt, M. (2010). 'Intergenerational Transmissions in Immigrant Self-employment: Evidence from Three Generations', Small Business Economics 34(3): 261-76. http://dx.doi.org/10.1007/s11187-008-9117-y

Andersson, P. \& Wadensjö, E. (2004a). 'Self-Employed Immigrants in Denmark and Sweden: A Way to Economic Self-Reliance?' Discussion Papers Series IZA DP No 1280. Bonn: Institute for the Study of Labor.

Andersson, P. \& Wadensjö, E. (2004b). 'Why Do Self-Employed Immigrants in Denmark and Sweden Have Such Low Incomes?' Discussion Papers Series IZA DP No 1280. Bonn: Institute for the Study of Labor.

Andersson, P. (2005). 'Self-employed Immigrants in Sweden: Are They Equally Successful as Natives?' Stockholm: Swedish Institute for Social Research, Stockholm University.

Andersson, P. (2006). Four Essays on Self-employment. Stockholm: Department of Economics, University of Stockholm.

Apitzsch, U. \& Kontos M. (2003). 'Self-employment, Gender and Migration', International Review of Sociology 13(1): 67-76. http://dx.doi.org/10.1080/0390670032000086989

Apitzsch, U. (2003). 'Gaining Autonomy in Self-employment Processes: The Biographical Embeddedness of Women's and Migrants' Business', International Review of Sociology-Revue Internationale de Sociologie 13(1): 163-82. http://dx.doi.org/10.1080/0390670032000087041

Aronsson, M. (1997). 'Svenska småföretagsforskare', in Bo Persson (ed.), Småföretagande, entreprenörskap och jobben. Stockholm: Rådet för arbetslivsforskning.

Barrett, G. Jones, T. \& McEnvoy, D. (1996). 'Ethnic Minority Business: Theoretical Discourse in Britain and North America', Urban Studies 33 (4/5): 783-809. http://dx.doi.org/10.1080/00420989650011825

Barrett, G. Jones, T. \& McEnvoy, D. (2003). 'United Kingdom: Severely Constrained Entrepreneurialism', in Robert Kloosterman and Jan Rath (eds), Immigrant Entrepreneurs: Venturing Abroad in the Age of Globalization. Oxford and New York: Berg.

Bevelander, P. Carlson, B. \& Rojas, M. (1997). I krusbärslandets storstäder. Om invandrare i Stockholm, Göteborg och Malmö. Stockholm: SNS Förlag. 
Björnsson, B. (2002). En bank även för kvinnor?: småföretagares erfarenheter av rådgivningsmöten i bank. Handelshögskolan Göteborg: Göteborgs universitet.

Bonacich, E. \& Modell, J. (1980). The Economic Basis of Ethnic Solidarity. Berkeley and Los Angeles: University of California Press.

Bonacich, E. (1973). 'A Theory of Middleman Minorities', American Sociological Review 38:583-94. http://dx.doi.org/10.2307/2094409

Campani, G. (2000). 'Immigrant Women in Southern Europe: Social Exclusion, Domestic Work and Prostitution in Italy', in King Russell, Gabriella Lazaridis and Charalambos Tsardanidis (eds), Eldorado or Fortress? Migration in Southern Europe. Houndmills: Macmillan.

Dalhammar, T. \& Brown, E.T. (2005). 'Industrial Effects on Resource Acquisition: Immigrant Enterprise in Kista, Stockholm', CESIS, Electronic Working Paper Series. The Royal Institute of Technology - Centre of Excellence for Studies in Science and Innovation; Stockholm, Paper No. 56.

Darin, K. (2006). 'Invandrarkvinnors företagande En studie av mötet mellan roller och strukturer', in Ewa Gunnarsson, Anders Neergard and Arne Nilsson (eds), Kors och tvärs. Stockholm: Normal.

Feldman, J. M. (2006). 'The Limits and Possibilities of Ethnic Entrepreneurship: The Case of ICT Firms in Sweden', International Journal of Multicultural Studies 8(1): 84-101.

Granovetter, M. (1985). 'Economic Action and Social Structure: The Problem of Embeddedness', American Journal of Sociology 91(3): 481-510. http://dx.doi.org/10.1086/228311

Haberfellner, R. (2003). 'Austria: Still a Highly Regulated Economy', in Robert Kloosterman and Jan Rath (eds.), Immigrant Entrepreneurs. Venturing Abroad in the Age of Globalization, Oxford and New York: Berg.

Hammarstedt, M. \& Shukur, G. (2009). 'Testing the Home-country Self-employment Hypothesis on Immigrants in Sweden, Applied Economics Letters 16(7): 745-48. http://dx.doi.org/10.1080/13504850701221907

Hammarstedt, M. (2001). 'Immigrant Self-employment in Sweden - its Variation and Some Possible Determinants', Entrepreneurship and Regional Development: An International Journal 13: 147-61. http://dx.doi.org/10.1080/08985620010004106

Hammarstedt, M. (2004). 'Self-Employment Among Immigrants in Sweden - An Analysis of Intragroup Differences', Small Business Economics 23: 115-26. http://dx.doi.org/10.1023/B:SBEJ.0000027664.58874.62

Hammarstedt, M. (2006). 'The Predicted Earnings Differential and Immigrant Self-employment in Sweden', Applied Economics 38: 619-30. http://dx.doi.org/10.1080/00036840500397069

Hammarstedt, M. (2009). 'Predicted Earnings and the Propensity for Self-employment: Evidence from Sweden', International Journal of Manpower 30(4 ): 349-59. http://dx.doi.org/10.1080/00036840500397069

Hjerm, M. (2001). 'Företagande, vägen till fattigdom eller frälsning för invandrare?', in $i$ Marginalisering eller integration? Invandrares företagande i svensk retorik och praktik - En forskningsrapport. Stockholm: NUTEK, Infonr. 032-2001.

Hjerm, M. (2004). 'Immigrant Entrepreneurship in the Swedish Welfare State', Sociology 38(4): 739-56. http://dx.doi.org/10.1177/0038038504045862

Hultman, H. (2006 ). 'Den gode invandraren bakar inte pizza - invandrares företagande i svensk forskning och politik', in Katarina Hjelm (ed.), Flervetenskapliga perspektiv i migrationsforskning. Arsbok 2006 från forskningsprofilen Arbetsmarknad, Migration och Etniska relationer (AMER) vid Växjö universitet. Växjö: Växjö University Press.

Jones, T. (1981). 'Small Business Development and the Asian Community in Britain', New Community 9: 467-77.

Jones, T. Barrett, G. \& McEvoy, D. (2000). 'Market Potential as a Decisive Influence on the Performance of Ethnic Minority Business', in Jan Rath (ed.), Immigrant Businesses - The Economic, Political and Social Environment. Houndmills, Basingstoke and London: Macmillan.

Jones, T. McEvoy, D. \& Barrett, G. (1993). 'Labour Intensive Practices in the Ethnic Minority Firm', in J. Atkinson and David Storey (eds), Employment, the Small Firm and the Labour Market. London: Routledge.

Khosravi, S. (1999). 'Displacement and Entrepreneurship: Iranian Small Businesses in Stockholm', Journal of Ethnic and Migration Studies 25 (3): 493-508. http://dx.doi.org/10.1080/1369183X.1999.9976697 
Khosravi, S. (2001). 'Klass och social status bland Iranska företagare', in i Marginalisering eller integration? Invandrares företagande i svensk retorik och praktik - En forskningsrapport. Stockholm: NUTEK, Infonr. 032-2001.

Kloosterman, R. \& Rath, J. (2001). 'Immigrant Entrepreneurs in Advanced Economies: Mixed Embeddedness Further Explored', Journal of Ethnic and Migration Studies 27(2): 189-202. http://dx.doi.org/10.1080/13691830020041561

Kloosterman, R. \& Rath, J. (2003). 'Introduction', in Robert Kloosterman and Jan Rath (eds.), Immigrant Entrepreneurs: Venturing Abroad in the Age of Globalization. Oxford and New York: Berg.

Kloosterman, R. van der Leun, J. \& Rath, J. (1999). 'Mixed Embeddedness: (In)formal Economic Activities and Immigrant Business in the Netherlands', International Journal of Urban and Regional Research 23: 252-66. http://dx.doi.org/10.1111/1468-2427.00194

Kontos, M. (2003). 'Self-employment Policies and Migrants' Entrepreneurship in Germany', Entrepreneurship \& Regional Development 15(2): 119-35. http://dx.doi.org/10.1080/0898562032000075131

Landström, H. \& Johansson, B. (1998). 'Theoretical Foundation in Swedish Entrepreneurship and Small Business Research', in: SIRE - The Centre for Venture Economics, Halmstad University, 25.

Lange, A. (2005). 'Utrikesfödda småföretagares villkor och verklighet', in Stockholm: NUTEK Infono. 002-2005.

Light, I. \& Bonacich, E. (1988). Immigrant Entrepreneurs: Koreans in Los Angeles 1965-1982. Berkeley and Los Angeles: University of California Press.

Light, I. \& Gold, S. (2000). Ethnic Economies. New York and London: Academic Press.

Light, I. \& Karageorgis, S. (1994). 'The Ethnic Economy', in Richard Swedberg and Niel J. Smelser (eds), The Handbook of Economic Sociology. Princeton \& New York: Princeton University Press \& Russell Sage Foundation.

Light, I. (1972). Ethnic Enterprise in North America: Business and Welfare among Chinese, Japanese, and Blacks. Berkeley and Los Angeles: University of California Press.

Light, I. (1984), Immigrant and ethnic enterprise in North America, Ethnic and Racial Studies, 7(2): 195-216.

Likic-Brboric, B. (2007). 'Globalisation, EU Enlargement and New Migratory Landscapes: The Challenge of the Informal Economy and Contingences for the "Decent Work", in Erik Berggren et al. (eds), Irregular Migration, Informal Labour and Community: A Challenge for Europe. Maastricht: Shaker Publishing.

Ljungar, E. (2007). Leverbröd eller entreprenörskap? Om utländskfödda personers företagande i Sverige. Stockholm: Department of Sociology, Stockholm University.

Lundquist, C. (2006a). 'Att vara sin egen. Unga företagare med utländsk bakgrund - villkor och strategier', in Integrationsverket \& NUTEK, R2006:03.

Lundquist, C. (2006b). 'Att vara sin egen. Unga företagare med utländsk bakgrund - villkor och strategier', in Integrationsverket \& NUTEK, R2006:03.

Lundquist, C. (2010). Möjligheternas horisont. Etnicitet, utbildning och arbete i ungas berättelser om karriärer, Linköpings studies in Art and Science. Linköping: ISV.

Lutz, H. (2002). 'At Your Service Madam! The Globalization of Domestic Service', Feminist Review 70: 89-104. http://dx.doi.org/10.1057/palgrave/fr/9400004

Lutz, H. (2005). 'The "Intimate Others" - Migrant Domestic Workers in Europe', paper read at International workshop: Migration, Informal Economy and Community in Europe, Istanbul, December.

Malheiros, J. M. (2000). 'Immigration, Clandestine Work and Labour Market Strategies: the Construction Sector in the Metropolitan Region of Lisbon', in King Russell, Gabriella Lazaridis and Charalambos Tsardanidis (eds), Eldorado or Fortress? Migration in Southern Europe. Houndmills and London: Macmillan.

Mason, S. \& Ålund A. (2001). 'Perceptions of Self-employment Policies and Practices', in Final Report for TSER projekt No. PL97 3211. Umeå, Sweden.

Mason, S. (2003). 'Self-employment Policies from the Perspective of Citizenship, Gender and Ethnicity', International Review of Sociology: Revue Internationale de Sociologie 13(1): 219-234. http://dx.doi.org/10.1080/0390670032000087078 
Mason, S. (2007). 'Collective Self-employment of Migrant Women in Sweden: Biographical Projects and Policy Measures', in Ursula Apitzsch and Maria Kontos (eds), Self-Employment Activities of Women and Minorities: Their Success or Failure in Relation to Social Citizenship Policies. Wiesbaden: VS Verlag für Sozialwissenschaften.

Mason-Almgren, S. (2002). Life in the Labyrinth: A Reflexive Exploration of Research and Politics. Umeå: Department of Culture and Media/Ethnology, Umeå University.

McEvoy, D. \& Jones, T. (1993). 'Relative Economic Welcomes: South Asian Retailing in Britain and Canada', in H. Rudolph and Mirjana Morokvasic (eds), Bridging States and Markets. Berlin: Edition Sigma.

Merton, R. K. (1973). The Sociology of Science - Theoretical and Empirical Investigations. Chicago and London: University of Chicago Press.

Morokvasic, M. (1988). 'Minority and Immigrant Women in Self-employment and Business in France, Great Britain, Italy, Portugal and Federal Republic of Germany', in Paris/Brussels.: V/1871/88, Report to the EEC.

Morokvasic, M. (1991 ). 'Roads to Independence: Self-employed Immigrants and Minority Women in Five European States', International Migration 29: 407-20.

Najib, A. B. (1999). Myten om invandrarföretaget. En jämförelse mellan invandrarföretagande och övrigt företagande i Sverige, Nya jobb och företag, Rapport No. 9: Stockholm, NUTEK.

Najib, A. B. (2000). 'Invandrdrföretagande. Livsverk eller påtvingad lösning?’ in Erik Olsson (ed.), Etnicitetens gränser och mångfald. Stockholm: Carlsson Bokförlag.

NUTEK (Swedish Agency for Economic \& Regional Growth) (2005), 'Den invandrade tillväxtkraften. Sammanfattning av rapporten: Utrikesfödda småföretagares villkor och verklighet', in Stockholm: NUTEK B 2005:6.

Näsman, B. (2000). Pappas flickor... : entreprenöriella processer i kvinnoföretagandets tillkomst. Stockholm: Företagsekonomiska institutionen, Stockholms universitet.

Pang, C. L. (2003). 'Belgium: From Proletarians to Proteans', in Robert Kloosterman and Jan Rath (eds), Immigrant Entrepreneurs. Venturing Abroad in the Age of Globalization. Oxford and New York: Berg.

Pettersson, K. (2002). Företagande män och osynliggjorda kvinnor : diskursen om Gnosjö ur ett könsperspektiv. Uppsala: Kulturgeografiska institutionen, Uppsala universitet.

Portes, A. \& Sensenbrenner, J. (1993). 'Embeddedness and Immigration - Notes on the Social Determinants of Economic Action', American Journal of Sociology 98(6): 1320-50.

Portes, Alejandro and Ruben G. Rumbaut (2001), Legacies: The Story of the Immigrant Second Generation. Berkeley: University of California Press.

Pripp, O. (2001a). Företagande i minoritet. Om etnicitet, strategier och resurser bland assyrier och syrianer i Södertälje. Stockholm: Mångkulturell centrum Botkyrka.

Pripp, O. (2001b). 'Strategier och organisering bland assyriska och syrianska företagare', in, i Marginalisering eller integration? Invandrares företagande i svensk retorik och praktik - En forskningsrapport. Stockholm: NUTEK, Infonr. 032-2001.

Ram, M. \& Jones, T. (2008). 'Ethnic-minority Businesses in the UK: A Review of Research and Policy Developments', Environment and Planning C: Government and Policy 26: 352-74. Doi:10.1068/c0722;

Rath, J. (2001). 'Research on Immigrant Ethnic Minorities in the Netherlands', in P. Ratckligge (ed.), The Politics of Social Science Research: 'Race', Ethnicity and Social Change. Houndmills, Basingstoke: Palgrave.

Rath, J. (2002). 'Needle Games: Mixed Embeddedness of Immigrant Entrepreneurs', in Jan Rath (ed.), Unravelling the Rag Trade: Immigrant Entrepreneurship in Seven World Cities. Oxford: Berg.

Rojas, M. (1993). 'Iransk, latinoamerikansk och polsk företagverksamhet i Malmöhus län 1989-1992', in Lund: Department of Economic History, Lund University, 26.

Rojas, M. (2001). Gemenskap och företagande: Företagande bland invandrare och minoroteter i USA. Stockholm: Timbro/CVV.

Skatteverket (2004), 'Insikt! Om invandrarföretagarna, rådgivarna och mötet med Skatteverket, SKV Rapport 2004:3', in Stockholm. 
Slavnic, Z. \& Urban, S. (2008). 'Socio-Economic Trends in the Swedish Taxi Sector - Deregulation, Recommodification, Ethnification', International Journal on Multicultural Societies 10(1): 76-94.

Slavnic, Z. (2001). 'Informell ekonomi och välfärdssamhället i ovandling', in i Marginalisering eller integration? Invandrares företagande $i$ svensk retorik och praktik. En förskningsrapport. Stockholm: NUTEK, Infonr.032-2001.

Slavnic, Z. (2004). 'Immigrant and Small Business Research in Sweden. An Overview', Norrköping, Occasional Papers and Reprints on Ethnic Studies, ThemES 2004:24.

Slavnic, Z. (2006). 'Ekonomins informalisering och arbetets rekomodifiering', in Anders Neergaard, Arne Nilsson and Ewa Gunnarsson (eds), Kors \& tvärs: Intersektionalitet och makt $i$ storstaden. Stockholm: Normal Förlag.

Slavnic, Z. (2007). 'Informalisation of the Economy and the Recommodification of Labour', in Erik Berggren et al. (eds), Irregular Migration, Informal Labour and Community: A Challenge for Europe. Maastricht: Shaker Publishing.

Slavnic, Z. (2010). 'Political Economy of Informalisation', European Societies 12(1): 3-24. http://dx.doi.org/10.1080/14616690903042724

Slavnic, Z. (2011). "Struggle for survival in the deregulated market: Re-commodification and Informalisation of the taxi sector in Stockholm", Forum for Social Economics 40(2): 233-251. http://dx.doi.org/10.1007/s12143-009-9060-y

Slavnic, Z. (2012). "Breaking out - barriers against effort, biographical work against opportunity structures" Journal of Business Administration Research 1(2): 1-17. http://dx.doi.org/10.5430/jbar.v1n2p1

SOU 1999:49 , 'Invandrare som företagare. För lika möjligheter och ökad tillväxt', in, Stockholm: Kulturdepartement.

SOU 2003:17 , 'Diskrimineras invandrarföretagare i Sverige. En empirisk studie av småföretagskonkurser under 1990-talet', in Rapport från Integrationspolitiska maktutredningen. Stockholm.

Waldinger, R. (1986). Immigrant Enterprise: A Critique and Reformulation, Theory and Society, 15(1-2): 249-85.

Waldinger, R. (1989). Structural Opportunity or Ethnic Advantage? Immigrant Business Development in New York, International Migration Review, 23(1): 48-72.

Waldinger, R. (1995). 'The "Other Side” of Embeddedness: A Case Study of Interplay of Economy and Ethnicity', Ethnic and Racial Studies 18: 555-79. http://dx.doi.org/10.1080/01419870.1995.9993879

Waldinger, R. (2001). 'The Immigrant Niche in Global City-regions: Concept, Patterns, Controversy', in A. Scott (ed.), Global City-regions: Trends, Theory, Policy. Oxford: Oxford University Press.

Waldinger, R., Aldrich H. et al. (1990). Ethnic entrepreneurs: immigrant business in industrial societies. London: Sage.

Williams, D. R. (2004). 'Youth Self Employment: Its Nature and Consequences', Small Business Economics 23(4): 323-36. http://dx.doi.org/10.1023/B:SBEJ.0000032035.30738.01

Wilpert, C. (2003). 'Germany: From Workers to Entrepreneurs', in Robert Kloosterman and Jan Rath (eds.), Immigrant Entrepreneurs. Venturing Abroad in the Age of Globalization. Oxford and New York: Berg.

Wilson, K. L. \& Martin A. W. (1982). 'Ethnic Enclaves: A Comparison of Cuban and Black Economies in Miami', American Journal of Sociology 88: 135-60.

Wilson, K. L. \& Portes, A. (1980). 'Immigrant Enclaves: A Comparison of Cuban and Black Economies in Miami', American Journal of Sociology 86: 295-319.

Wokander, M. (2004). Skattmasens Manifest: Stockholm, Efron \& Dotter.

\section{Selection of other relevant literature from Swedish ISBR}

Abbasian, S. \& Bildt, B. (2009), 'Empowerment through Entrepreneurship - A Tool for Integration among Immigrant Women?' CISEG Working Papers Series. Jönköping: Centre for Innovation Systems, Entrepreneurship and Growth, Jönköping International Business School.

Abbasian, S. (2000). 'Bosättningsmönster, eget företagande och integration', in Göteborg: Kulturgeografiska institutionen, Handelshögskolan, Göteborgs universitet, 124.

Ahlstrand, S. \& Johansson, A. (2005). 'Etnicitetsdrivet företagande finns i Norrköping - exempel \& förslag på hur det kan tillvaratas', in Norrköping: Norrköpings kommun, Näringslivskontoret, November. 
Ahlstrand, S. and Björkman J. (2004). 'Finns Etnicitetsdrivet Företagande i Norrköping - och i så fall vad betyder det?' in Norrköping: Norrköpings kommun, Näringslivskontoret, Oktober.

Anderson, C. (2008). 'Invandrarägda företag och dess affärer med den offentliga sektorn', in Stockholm: IFS.

Andersson, R. (2008) Implementering av integrationspåolitik i den regionela utvecklingspolitiken, 1984-2004. Flernivåstyrning av komplexa mål genomnätverk. Norrköping: Licentiatavhandling, Linköpings universitet.

Gür, T. (1999). 'Svälj inte kamelerna - om att förbättra för etnisk företagande', in SOU 1999:49 Invandrare som företagare. För lika möjligheter och ökad tillväxt. Stockholm, Kulturdepartement.

Habib, H. B. (2001). 'Mångfalden döljer proletariat', Dagens nyheter, 01-02-21, A4.

Habib, Hedi Bel (1999), 'Från invandrarföretagsamhet till generell tillväxtdynamik', in SOU 1999:49 Invandrare som företagare. För lika möjligheter och ökad tillväxt. Kulturdepartement.

Hudson, C. (2001) 'Regionala partnerskap - et hot mot eller ett förverkligande av demokraty?' in Umeå: Statsvetenskapliga institutionen, Umeå universitet.

Hudson, C. (2005). 'Regional Development Partnerships in Sweden: Putting the Government back in Governance?' Regional and Federal Studies 15(3): 311-27. http://dx.doi.org/10.1080/13597560500223297

Högström, J. (2003). Konstruktionen av företagare som diskursiva subjekt - en diskursanalytisk studie av hur kvinnor och män representeras som företagare i tidningen Eget Företag. Norrköping: Institutionen för tematisk utbildning och forskning - ITUF, Linköpings universitet, Campus Norrköping.

Joona-Andersson P. \& Wadensjo, E. (2009). 'The Employees of Native and Immigrant Self-employed', Research in Labor Economics 29: 229-50. http://dx.doi.org/10.1108/S0147-9121(2009)0000029011

Joona-Andersson, P. \& Wadensjö E. (2008). 'A Note on Immigrant Representation in Temporary Agency Work and Self-employment in Sweden', LABOUR 22(3): 495-507. http://dx.doi.org/10.1111/j.1467-9914.2008.00425.x

Klinthäll, M. (2008). 'Kartläggning av invandrarföretagande i Norrköping och Linköping', in Norrköping: Mimeo, REMESO.

LänsstyrelseniStockholm (2006), 'Entreprenörer utan kapital', in Stockholm: Länsstyrelsen i Stockholms Län. Rapport 2006:23.

LänsstyrelsenÖstergötland (2003), 'Att vara företagare och invandrare i Östergötland. Intervjuundersökning med 39 företagare', in Länsstyrelsen Östergötland.

Martinovic-Landerholm E. (2005). Invandrarföretagare i Sverige - kritisk diskursanalys av hur riksdag och regering talar om invandrarföretagare. Norrköping: Linköpings universitet, Campus Norrköping.

Najib, A. (1992). 'Invandrarföretagande i Uppsala - en värdefull resurs', in Uppsala: Kulturgeografiska institutionen vid Uppsala universitet.

Najib, A. (1994). 'Immigrant Small Businesses in Upsala. Disadvantage in Labour Market and Success in Small Business Activities', in Upsala: Department of Social and Economic Geography, 108.

Najib, A. (1997). 'Invandrarföretagande. Inte enbart pizzerior', in Bo Persson (ed.), Småföretagande, Entreprenörskap och jobben. Ett forskningsfält i förrendring. Stockholm: Rådet för arbetslivsförskning.

Najib, A. (1999). 'Invandrarföretagande - några grundläggande fakta', in SOU 1999:49 Invandrare som företagare. För lika möjligheter och ökad tillväxt: Kulturdepartement.

Nordlund, S. (1999). 'Invandrarföretagande i Sverige - en historisk tillbackablick', in SOU 1999:49 Invandrare som företagare. För lika möjligheter och ökad tillväxt: Kulturdepartement.

Nordlund, S. (1999). 'Kommentarer eller synpunkter rörande insatser för att åstadkommalika behandling av rörelseidkare oavsett etnisk och kulturell bakgrund', in SOU 1999:49 Invandrare som företagare. För lika möjligheter och ökad tillväxt: Kulturdepartement.

NUTEK (2001). 'Invandrares företagande i Sverige. Kartläggning och analys', in Stockholm: NUTEK Infonr 004-2001.

NUTEK (2001). 'Marginalisering eller integration - Invandrares företagande i svensk retorik och praktik. En forskarantologi', in Stockholm: NUTEK Infonr 032-2001.

NUTEK (2002:9). 'Företagens villkor och verklighet. Dokumentation och svarsöversikt', in Stockholm: NUTEK. 
NUTEK (2003:2). 'Företagens villkor och verklighet. Miljöarbete i småföretag - en ren vinst?' in Stockholm: NUTEK.

NUTEK (2003:4). 'Företagens villkor och verklighet. Tillväxt i småföretag', in Stockholm: NUTEK.

NUTEK (2003:6). 'Företagens villkor och verklighet. Småföretags förväntningar på ett svneskt EMU-inträde’, in Stockholm: NUTEK.

NUTEK (2003:7). 'Företagens villkor och verklighet. Kvinnors företagande - format av samhället', in Stockholm: NUTEK.

NUTEK (2004). 'SMEs in Sweden. Struktural Change and Policy Development', in Stockholm: NUTEK Infono 002-2004.

NUTEK (2004:1). 'Företagens villkor och verklighet. IT i småföretag: Regionakla skilnader i användningen av IT', in Stockholm: NUTEK.

NUTEK (2006). 'Att vara sin egen. Unga företagare med utländsk bakgrund - villkor och strategier', in: Integrationsverket \& NUTEK, R2006:03.

NUTEK (2006). 'Villkor och strategier för unga företagare med utländsk bakgrund. Handlingsvilkor, förhållningssätt samt resurser för unga företagare med utändsk bakgrund', in: Integrationsverket \& NUTEK, R 2006:08.

NUTEK (2007). 'Invandrares företagande. En studie av utlandsfödda företagare i Sverige', in Stockholm: NUTEK R 2007:22.

NUTEK (2007). 'På väg mot ett fokuserat tillväxtarbete - Regionala tillväxtprogrammen 2006', in Stockholm: NUTEK Infonr 028-2007.

Olofsson, K. \& Rydvall, J. (2004). Vad skulle jag starta, en pizzeria?'. En sociologisk analys av varför nio invandrare valt att starta egna företag och deras situation som egenföretagare i Sverige. Lund Sociologiska institutionen, Lunds universitet.

Persson, B. (1997). 'Från arbetslösheten till underföretagande', in Bo Persson (ed.), Småföretagande, entreprenöskap och jobben - Ett forskningsfält i förändring. Stockholm: Rådet för arbetslivsforskning.

Pripp, O. (1994). Att vara sin egen. Om småföretagande bland invandrare - mönster, motiv och möten. Stockholm: Mångkulturell centrum, Sveriges Invandrarinstitut och Museum.

Pripp, O. (1999), 'Immigranter och småföretagande’, in, SOU 1999:49 Invandrare som företagare. För lika möjligheter och ökad tillväxt: Kulturdepartement.

Prop.1997/98:62 (1998), 'Regional tillväxt - för arbete och välfärd', in Stockholm.

Prop.2001/02:04 (2001), 'En politik för tillväxt och livskraft för häla landet', in Stockholm.

Salminen-Karlsson, M. \& Sundin, E. (2001). 'Kvinnor som företagare, invandrare som företagare - om llikheter och olikheter i retoriken', in $i$ Marginalisering eller integration? Invandrares företagande i svensk retorik och praktik - En forskningsrapport, Stockholm: NUTEK, Infonr. 032-2001.

Slavnic, Z. (2007). 'Forskning och politik relaterat till småföretagande bland invandrare i Sverige', in Rapport Nr: 2007:21. Linköping: Länsstyrelsen Östergötland.

SOU1996:55 (1996). 'På väg till egen företagande', in Stockholm: Arbetsmarknadsdepartement.

SOU2003:17 (2003). 'Diskrimineras invandrarföretagare i Sverige. En empirisk studie av småföretagskonkurser under 1990-talet', in Rapport från Integrationspolitiska maktutredningen. Stockholm.

SOU2008:56 (2008). 'Mångfald som möjlighet - Åtgärder för ökad integration på landsbygden', in Stockholm: Jordbruksdepartementet.

Stein, P. (2000). 'Invandrarna - de nya svenska entreprenörerna. En undersökning av invandrarföretagens villkor i Sverige', in Stockholm: Svensk Handel.

Stevenson, L. \& Lundström, A. (2001). 'Patterns and Trends in Entrepreneurship/SME Policy and Practice in Ten Economies', in Entrepreneurship Policy for the Future Series, Volume 3. Stockholm, Swedish Foundation for Small Business Research.

Urban, S. \& Slavnic, Z. (2008). "Etnisk märkning av taxibranschen." Dansk Sociologi 19(1): 53 - 72. 
Wiklund, J. (1999). 'Generella drag hos snabbväxande småföretag', in,] SOU 1999:49 Invandrare som företagare. För lika möjligheter och ökad tillväxt: Kulturdepartement.

VästraGötalandsregion (2006), 'Vem är företagare i Västra Götaland? Rapport tillväxt och utveckling', in Västra Götalandsregion.

Önal, A. \& Rezania, F. (2007). 'Kusinen eller banken? Finansieringsmöjligheter bland företagare med invandrarbakgrund', in Stockholm: Svenskt näringsliv.

\section{Notes}

Note 1. See for instance Barrett, Jones \& McEnvoy (1996; 2003); Jones (1981); Jones et al. 1993 Jones, Barrett \& McEvoy (2000); McEnvoy och Jones (1993).

Note 2. Kloosterman, van der Leun \& Rath (1999); Kloosterman \& Rath (2001); Rath (2002); Kloosterman \& Rath (2003).

Note 3. Apitzsch (2003); Kontos (2003); Apitzsch \& Kontos (2003).

Note 4. Mirjana Morokvasic was one of the first scientists who already in the 1980 s tried to draw attention to immigrant women's situation both within and outside the labour market in Western societies, but also within ethnic entrepreneurship (Morokvasic 1988; 1991).But only in the 2000s did a range of texts appear on various aspects of the entrepreneurship of women with foreign backgrounds. These texts include Andall (2000), Campani (2000), Malheiros (2000), Lutz (2002; 2005); Apitzsch \& Kontos (2003).

Note 5. Now Linnaeus University.

Note 6. See Hammarstedt (2004; 2006; 2009), Hammarstedt \& Shukur (2009), Ahmed, Andersson \& Hammarstedt (2009) and Andersson \& Hammarstedt (2010). 